\title{
O NEGACIONISMO NA OPOSIÇÁO DE JAIR BOLSONARO À COMISSÃO NACIONAL DA VERDADE
}

\section{Pablo Emanuel Romero Almada (iD}

E-mail: pablo.almada@unesp.br.

Universidade Estadual Paulista Júlio de Mesquita Filho (UNESP) Araraquara-SP, Brasil.

DOI: $10.1590 / 3610608 / 2021$

\section{Introdução}

As relaçóes entre a política e a memória têm colocado diversos conflitos em torno dos sentidos e das conotaçóes dos acontecimentos do passado e seus efeitos no tempo presente. Nos últimos anos, a presença de um discurso político conservador é um fenômeno que tem despertado a devida atenção por parte de estudiosos e especialistas das Ciências Humanas e Sociais, procurando desvendar essas ideologias e seus discursos, os quais pairam sobre a política brasileira atual.

Em seu sexto mandato como Deputado Federal pelo estado do Rio de Janeiro (2011 - 2014), o atual Presidente da República Federativa do Brasil, Jair Messias Bolsonaro, se posicionou de forma polêmica sobre temas de repercussão na agenda política,

Artigo recebido em: 26/02/2020

Aprovado em: 20/09/2020 conseguindo destaque nas redes sociais, agindo em oposição aos governos de Dilma Rousseff, em especial por seu papel na defesa da ditadura militar e de suas práticas políticas arbitrárias.

$\mathrm{O}$ artigo analisará o negacionismo que pautou as suas críticas à Comissão Nacional da Verdade (CNV), de modo a perceber suas imbricaçóes com uma linguagem política construída sobre a recusa das possibilidades de reconhecimento das violaçóes de direitos humanos pelo Estado brasileiro durante a Ditadura Civil-Militar. Para tanto, considera-se que a linguagem política cria contextos sobre os atores, de modo a se configurar também como "um tema de discussão prescrito para o discurso político" (Pocock, 2003, p. 37). E, nesse caso, trata-se de compreender os termos negacionistas utilizados para sua defesa da ditadura civil-militar em detrimento do papel de promoção da justiça de transição e sobretudo da memória e do conhecimento sobre o passado. 
Admite-se, como hipótese, que Jair Bolsonaro expressa, em relação à $\mathrm{CNV}$, uma combinação de diversos elementos do negacionismo que possibilitam a construção de histórias alternativas e colocam em evidência a recusa de 1964 como um golpe, ao culpar a esquerda pela violência do passado, operando um aberto sentido de manipulação dos fatos do passado e seus usos no tempo presente, mantendo a interdição da memória como projeto político.

\section{O negacionismo: do revisionismo à história alternativa}

O revisionismo histórico insere-se em um campo de debates da História Moderna e Contemporânea, de modo a reconsiderar como alguns dos acontecimentos do passado se inserem no tempo presente, na formação de identidades coletivas e de discursos políticos e nas reminiscências da memória. Concomitante às renovaçóes epistemológicas e metodológicas da História, que abriram caminho para a História do Tempo Presente e sua intrínseca relação com a memória (Sandoica, 2004), as interpretaçóes históricas ocorrem de acordo com as mudanças das interpretaçóes do passado no tempo presente.

Primeiramente, identifica-se um procedimento acadêmico de avanço do conhecimento do passado (Capelato, 2016, p. 21), suscitando uma "revisáo historiográfica”, orientada pela descoberta de novas evidências, ou por mudanças quanto aos valores que os historiadores consideram significativos, ou ainda, pela reavaliação de eventos e processos históricos descritivos e explicativos (Tucker, 2007, p. 1 - 3). As especificidades e diferenças deste revisionismo são ainda mais amplas e contraditórias conforme se analisa os debates suscitados pela historiografia marxista, que tanto podem identificar visóes reformistas do marxismo, como também podem sugerir debates em torno do revisionismo acadêmico da segunda metade do século $\mathrm{XX}$, no que concerne a uma possível "desqualificação do conceito de revoluçáo” (Melo, 2014, p. 21).

Um segundo sentido para o revisionismo é aquele suscitado por interesses não acadêmicos, desprendidos dos padrôes e métodos da disciplina. Este revisionismo produz resultados que podem "manipula[r] dados-fatos e apresenta[r] interpreta[çóes] deturpada[s] do passado, com informaçóes imprecisas e descontextualizadas em relação aos acontecimentos”, servindo a motivaçôes político-partidárias em contextos de crise (Capelato, 2016, p. 22), por isso, não obtém reconhecimento na historiografia e tampouco seriam aceitos no debate público (Traverso, 2017, p. 27). Ao afetar diretamente a identidade do tempo presente, essas controvérsias revisionistas de cunho manipulatório apontam para a existência de uma história oficial, normativa e legítima, a qual é supostamente defendida por essa visão. Por isso, esta

historiografia revisionista” assume a forma de uma "historiografia terapêutica, que classifica as proposiçóes (...) de acordo com seus efeitos no bem-estar psicológico do público-alvo", de modo a utilizar-se da "negação da culpa histórica (...); a promoção do respeito próprio (...) por mitos nacionais; e a eliminação de um senso de alienação e absurdo (...) através de teorias da conspiração. (Tucker, 2007, p. 3 - 5)

A negação da história oficial e suposição de outra história que ainda deve ser revelada é um dos elementos teóricos que identificam essa historiografia revisionista manipulatória.

O revisionismo da Historikerstreit, a "querela dos historiadores", é comumente questionado e inscrito neste modelo, dada a equiparaçáo do nazismo com o bolchevismo, mediante seus casos de violência e de extermínio, além da culpabilização dos grupos de esquerda por massacres e por justiçamento de seus aliados (Melo, 2014, p. 31 - 32). É possível também diferenciar algumas questóes dessa matriz teórica que a diferenciam do que se pode chamar de negacionismo. Primeiramente, a Historikerstreit encontra diversos pontos em comum com o revisionismo soviético dos anos 1970, o qual analisava este regime na matriz do totalitarismo, construído de cima para baixo pelo controle e pela manipulação, com amplo uso do terror e da propaganda, embora também houvesse a incursão em pensar o "apoio social deste regime" (Fitzpatrick, 2007, p. 80 - 81). Em segundo lugar, essa historiografia " "não negou as evidências relevantes que levaram ao consenso historiográfico sobre os eventos do Holocausto", atribuindo ao bolchevismo a causa 
do nazismo e, consequentemente, dividindo as responsabilidades nas atrocidades cometidas com os comunistas (Tucker, 2007, p. 10). Portanto, a Historikerstreit não pode ser confundida com o negacionismo aqui teorizado, já que este último caminha por desconsiderar evidências factuais, em prol de uma postura meramente política.

A concepção de negacionismo é, primeiramente, aquela que retorce as evidências históricas, fugindo do escopo acadêmico e que oferece uma "interpretação alternativa à abordagem classificada (...) de exterminacionista" (Melo, 2014, p. 40). Entendida como um "revisionismo absoluto", essa concepção considera que "o genocídio praticado na Alemanha nazista contra os Judeus e Ciganos não existiu e pertence ao dominio do mito, da fabulação, da fraude" (Vidal-Naquet, 1988, p. 117). A negação da violência, da tortura e da existência do genocídio nazista com seus métodos perversos projeta um simbolismo perpassado nas e pelas gerações posteriores, referindo-se diretamente à memória, sua manipulaçáo e assassinato. Em partes isso reside na relutância do reconhecimento de documentos comprobatórios ou do uso de métodos pouco rigorosos nas análises das fontes, ou recorrendo a simples ilações deliberadas, resultando em um alinhamento com posturas nacionalistas, neonazistas, antissemitas ou antissionistas (Vidal-Naquet, 1988, p. $40-41)$.

Portanto, se o negacionismo pode ser entendido como uma manipulaçáo política da história, ele pretende não apenas eximir a culpa de algozes quanto a determinadas violências e extermínios, mas apagar os próprios fatos e sua memória, para que não exista algozes e que estes sejam vistos como heróis. $\mathrm{O}$ negacionismo pretende, desse modo, "transformar os assassinos da memória em vítimas de uma censura, defensores da liberdade de expressão" (Traverso, 2017, p. 37). Como o negacionismo é recusado dos debates acadêmicos, o mesmo não se pode dizer em relaçấo a sua presença no espaço público, pois ainda que haja uma dificuldade de sua aceitação (Traverso, 2017, p. 27), sua atual construçáo e pertinência estáo relacionados com o crescimento de grupos da extrema-direita por todo o mundo.

Estes grupos têm mobilizado e aprimorado elementos do negacionismo para a formação de sua identidade e linguagem política. É exatamente isso que se pode notar em relação ao conceito de AltHistory, ou História Alternativa, a qual é "construida por propósitos ideológicos através da negação da história" (Valencia-García, 2020, p. 13). As manipulaçōes da história, tecidas pela recusa dos próprios argumentos do revisionismo, permitiram que diversas dimensóes fossem criadas e articuladas, como: a negação histórica de arquivos e evidências históricas; a crença na história cíclica ou teleológica; as narrativas que assumem uma teoria da degeneração ao invés da compreensão da mudança; a mitologização presente na substituição de fatos por quimeras; a nostalgia por um passado imaginado, selecionando fatos e narrativas históricas; a presença de um a-historicismo baseado na mentira; o aproveitamento da memória fragmentada e tendenciosa presente na memória pública popular (Valencia-García, 2020, p. 9). Essa amplitude de sentidos que inscreve a história alternativa, no que lhe concerne, utiliza-se do presente para justificar um entendimento sobre o passado, criando uma linha do tempo alternativa, que produz uma distorçáo intencional dos fatos. Contudo, a preocupação dessa vertente não é a historiografia, mas as crenças e ideologias que necessitam alterar os fatos e suas interpretaçóes para que determinados posicionamentos políticos passem a fazer sentido, ou que sejam vistos e debatidos na esfera pública. Ressalta-se que as distorçôes da memória pública, ou da forma como o público se remete ao passado, ultrapassam a visáo de seus ideólogos, estando presente na própria esfera pública em meio a tensões com os especialistas.

Os grupos da extrema-direita, que tem se mobilizado pela criação de uma Alt-History, na verdade, buscam inserir suas visóes ideológicas outrora recusadas nesse debate, argumentando por sua legitimidade e pelo não reconhecimento das versôes oficiais dos fatos, tão verdadeiras quanto àquelas produzidas pelos historiadores e pesquisadores, muitas vezes, enfatizando em demasia apenas alguns fatos em detrimento de outros ou de uma compreensão mais geral do problema. Desse modo, planeja-se uma inversão de vítimas e algozes, dado que "histórias alternativas são usadas para exaltar os culpados, culpando um grupo marginalizado" (Valencia-García, 2020, p. 14). A história alternativa não apenas se distancia dos processos científicos e 
metodológicos da historiografia, mas passa a nutrir o campo dos conflitos pela memória, aproveitando-se dos silenciamentos e esquecimentos.

\section{A inexistência da ditadura}

No caso do contexto brasileiro, a investigação permitida por essa questáo conduz às reflexóes pertinentes à Ditadura Civil-Militar (1964-1985), ${ }^{1}$ quanto à sua pertinência na memória e no tempo presente, de modo a indagar as possibilidades do negacionismo e as tendências de construção de uma história alternativa que "assassina” a memória. Para tanto, o próprio caráter da repressão e da censura provocou um sentido de inexistencialismo da ditadura, já que esta trata de

realidades inexistentes para a maior parte da população brasileira, não simbolizadas portanto e ausentes na memória e em uma certa construçáo da história”, o que conduz a um paradoxo "de não poder esquecer, pois o esquecimento só épossivel quando algo foi registrado na ordem simbólica (Cardoso, 2003, p. 171).

Se, por um lado, há uma "diluição na memória coletiva dos eventos da repressão”, há também uma “cicatrização" dada pela Lei da Anistia de 1979, que impôs o esquecimento por meio de "um acordo, não escrito, entre as diversas facçóes militares, de que a abertura não levaria à investigação do passado e, ao compromisso de que o aparelho repressivo não seria investigado, nem julgado" (Cardoso, 2003, p. 173 - 174).

Como salienta Pinha (2020, 1. 4602), o processo de anistia se edificou sobre a "equivalência entre as violências cometidas pelo Estado e pelas organizaçóes de luta armada, responsabilizando a todos (...), incentivando o esquecimento recíproco, a desmemória e o pacto de silêncio". A referência de igualdade entre as partes quanto aos crimes cometidos, o que convencionou-se a chamar, a partir da experiência argentina, de "teoria dos dois demônios”, permitiu a construção de uma situação de não-ruptura, favorável ao apagamento do passado e suscitando "permanências autoritárias, no presente, no interior desse regime democrático" (Pinha, 2020,
1. 4623). Por essa razão, argumenta Pereira (2015), haveria um "regime de não inscrição" da Ditadura CivilMilitar na memória coletiva, estando em passagem, ainda que sutil, para um "regime de inscriçâo frágil" (Pereira, 2015, p. 865), e que, desse modo, a criação e implementação da Comissão Nacional da Verdade poderia suscitar batalhas pela inscrição na memória, ainda que possa gerar efeitos inversos.

Se a história depende também de uma elaboração da memória, em um contexto de negação da história verifica-se com alguma tangibilidade as elaboraçóes alternativas e manipulaçóes dos fatos, explorando as fissuras do esquecimento e a não-inscrição do passado na memória. A “fenda autoritária” (Pinha, 2020) existe na Lei da Anistia e na Constituição Federal de 1988, permitindo o negacionismo, a construção de histórias alternativas e o esquecimento, que beneficiam vencedores, torturadores e violadores de direitos humanos.

Considerando esse panorama na ampla historiografia da Ditadura Civil-Militar, o revisionismo se faz presente em linhas muito tênues. Ao se considerar a "ditabranda", ao rever os papéis da esquerda e suas inconsequências, ou ainda, nos relatos posteriores $\mathrm{da}$ mídia, mas sobretudo, nas revisitações da tomada de poder dos militares em 1964, é aberto um espaço de revisão historiográfica, que pode ser tanto acadêmico quanto político e manipulatório. No entanto, uma historiografia assumidamente negacionista tende a ser residual, já que são obras de difícil reconhecimento pelas ciências humanas, devido à ausência de trato acadêmico e evidente manipulação. De acordo com Wainberg (2010), em uma amostragem de 347 obras sobre a ditadura militar, escritas entre 1964 e 2009, são majoritários o caráter testemunhal, a ótica das esquerdas e o apelo de denúncia ao regime e ao golpe de 1964, havendo poucas obras de testemunhos da direita, embora costumem denunciar açóes subversivas de grupos tidos como terroristas.

Em 1979, com pouca repercussão nos círculos militares, o ex-chefe de gabinete de Castello Branco e seguidor da "linha dura”, Jayme Portella de Mello, publicou $A$ revolução e o governo Costa e Silva. Anos mais tarde, com um tom marcadamente revisionista e negacionista, foi organizado o Orvil - Tentativas de tomada do poder (1985), escrito pelo Centro de 
Informaçóes do Exército (CIEE) e organizado pelo Tenente-Coronel Lício Maciel e pelo Tenente José Conegundes do Nascimento. Esta obra foi uma resposta ao Projeto Brasil Nunca Mais, organizado por D. Paulo Evaristo Arns e teve, na altura, a sua publicação proibida.

Outras obras foram escritas pelo ex-chefe do Doi-Codi do II Exército Maior e primeiro oficial condenado, no ano de 2008, por crimes de sequestro e tortura, Carlos Alberto Brilhante Ustra: Rompendo o Silêncio (1987) e A verdade sufocada: A história que a esquerda não quer que o Brasil conheça (2006), a qual foi reeditada e amplamente execrada pelos especialistas, de acordo com os motivos anteriormente citados. Outros escritos mais recentes e desvinculados dos círculos militares, mas que assumem o tom negacionista, são os do escritor Olavo de Carvalho, compilados em $O$ imbecil coletivo (1996) e especialmente em $O$ minimo que você precisa saber para não ser um idiota (2013). ${ }^{2}$

Em torno dessas questões, se identificam alguns aspectos que embasam esse movimento negacionista: a utilização da teoria da guerra revolucionária por parte do discurso militar e o uso de fontes da mídia e seus editoriais como embasamento factual. O contexto de 1964 articulou fatores que transladaram desde a renúncia de Jânio Quadros até a recusa das forças políticas em aceitar João Goulart e a opção pelo parlamentarismo, além da pressão dos movimentos de base, organizados desde o final dos anos 1950 . Assim, a historiografia consolidou posteriormente diversos modos de análise para o golpe de 1964, percebendo a aproximaçáo dos militares à cena política nacional (Alfred Stepan), as relaçōes entre os interesses do capital internacional e os blocos de poder (René Armand Dreifuss), o desenvolvimentismo associado-dependente (Fernando Henrique Cardoso), os cálculos de conflito e estabilidade em conjuntura de populismo (Wanderley Guilherme dos Santos), as ideias de ação política conjuntural e de rupturas dos compromissos com a democracia por parte das esquerdas e das direitas (Daniel Aarão Reis Filho) (Fico, 2004).

Embora o clima político favorecesse "o espectro de um golpe, seja de direita ou de esquerda" (Figueiredo, 2015 , p. 35), somente as alas da direita haviam se fortalecido de fato, sendo que a esquerda se apoiava massivamente sobre a estrutura parlamentar, liderada pelo Partido Trabalhista Brasileiro (PTB). O crescimento da influência dos setores militares na sociedade, em especial sobre a União Democrática Nacional (UDN), permitiu que houvesse a incorporação de um discurso proveniente da "guerra revolucionária". Esse fato acabou por inviabilizar uma saída constitucional e congressista para a crise política estabelecida, afinal, como reação prévia a um possível processo revolucionário, de esquerda, o AI - I autolegitimava a ideia de "revolução", em curso na altura (Martins Filho, 2019). Apesar das Forças Armadas constituírem um campo difuso de posiçôes políticas e de aproximaçóes com outros setores sociais, "a tese da defesa da legalidade forneceu um forte argumento para quebrar a resistência dos setores legalistas das Forças Armadas e para unificar os militares"(Figueiredo, 2015, p. 37). Assim, forjouse um consenso entre militares e setores de direita da sociedade civil em torno da ideia de que para defender a democracia era necessário a ruptura com as regras democráticas, a partir de mobilizaçóes da opiniáo pública em torno dessa questáo.

Em relação ao aparentemente difuso campo militar, havia em seu interior, desde 1959, a crescente incorporação da doutrina da "guerra revolucionária" (Martins Filho, 2008). Formulada a partir de excombatentes franceses na Argélia, militares do Brasil e da Argentina aceitaram-na de modo irrestrito, já que os seus preceitos relacionavam desde a combinaçáo entre política, ideologia e meios militares e não-militares, até a preconização de uma "intervenção militar na sociedade"(Martins Filho, 2008, p. 41). Por identificar o inimigo a ser combatido como aquele que propóe a guerra revolucionária, focalizou-se que a esquerda e os grupos comunistas estariam se organizando para uma tomada de poder no Brasil. O Estado-Maior das Forças Armadas interpretava que a ordem estava sendo subvertida por infiltrados, formados no exterior e com amplo acesso às armas, constataçôes estas que eram divulgadas nos cursos de formação de militares e que nutriam o aspecto ideológico das mais variadas patentes e graus hierárquicos da corporação.

Por outro lado, a imprensa brasileira assumiu, desde 1962, uma postura de oposição ao governo de João Goulart. A partir de "um bloco da imprensa contra o governo" (Napolitano, 2016, p. 45), liderado pelo 
Jornal do Brasil, em diversos editoriais bradava-se o desejo de depor Jango. A articulação da chamada Rede da Democracia, composta pelos principais jornais do país, aceitava e divulgava a tese de que havia forças comunistas e subversivas prontas para tomar o poder, sobretudo, na Presidência da República. Assim sendo, "a imprensa preparou o clima para que os golpistas (...) se sentissem mais amparados pela opiniäo pública ou, ao menos, pela opiniāo publicada"(Napolitano, 2016, p. 46 - 47). Cabe mencionar que essa postura de apoio ao golpe nunca foi revista de modo massivo pela imprensa, ocorrendo apenas críticas pontuais e contextuais aos planos econômicos e às diferenças de governo (Napolitano, 2017).

Para desmistificar a tese dos militares e da imprensa do período, acerca de uma possível guerra revolucionária em curso e de uma tomada de poder iminente pela esquerda, deve-se ter em conta o comportamento político da esquerda brasileira.

A tomada de uma posição pela luta armada era algo ainda bastante incipiente, fato que somente ganharia corpo nos debates anos depois de 1964. $\mathrm{O}$ PCB vivia um momento de desmembramentos, inaugurados em 1962 com a fundaçáo do $\mathrm{PCDOB}$ e seguido por mudanças de postura perante a renúncia de Jânio Quadros e a posse de João Goulart, oscilando entre o otimismo e a desilusáo com Jango. Sua postura buscava majoritariamente um diálogo reformista com Jango e, no limite, alguma mobilização popular. A Polop buscava consolidar-se como força de esquerda, eventualmente como partido político, apostando nas mobilizações populares iniciadas nos anos anteriores. O PCDOB observava a degradaçáo crescente das relaçôes produtivas nacionais, sendo otimista em relação ao advento de uma revolução proletária a partir da almejada tomada de consciência dos trabalhadores, mas não vislumbrava essa situação já em 1964, mas como um movimento que ainda seria construído. $\mathrm{O}$ desafio posto para a esquerda brasileira naquele momento encarnava três conjecturas: o caráter da revolução, as formas de luta para se chegar ao poder e o modelo de organizaçáo revolucionária para isso (Ridenti, 2010). Não obstante, o amadurecimento de uma possibilidade de "luta armada" somente pode ser percebido após 1964, pois o $\mathrm{PCDOB}$ e a AP preferiam optar pela "guerra popular prolongada", sem efetivar açôes armadas nas cidades (Ridenti, 2010, p. 46), mas deslocando os militantes para o foco rural da guerrilha que organizaria o campesinato, objetivos pretendidos pela Guerrilha do Araguaia anos mais tarde. Foi apenas no contexto de 1967 e 1968 que as opçóes foquistas passam a estar presentes, com o Movimento Revolucionário 8 de Outubro (MR-8) e com o Comando de Libertação Nacional (Colina), que se interessavam pela criaçáo de um foco militar armado liderado pelo campesinato. A Aliança Libertadora Nacional (ALN) abdicou parcialmente do foquismo e procurava implementar as "colunas guerrilheiras móveis", como vanguarda política (Ridenti, 2010, p. 47).

Essas condiçóes políticas objetivas da esquerda brasileira afastam as possibilidades argumentadas pela doutrina da guerra revolucionária e pela grande imprensa, de modo a apontar os limites dos argumentos que sustentam o golpe preventivo.

Percebe-se que, ao longo dos anos, as várias vertentes simpatizantes do golpe de direita encontraram na imprensa um agregador de suas vozes. Assim, as representaçóes posteriores do golpe de 1964 terão como principal referência a imprensa escrita e os sentidos de esvaziamento das disputas e das tensóes da ditadura militar (Biroli, 2009). Um exemplo disso é o discurso da chamada "ditabranda", por parte da Folha de $S$. Paulo (Silva, 2014), o que ensejou, mais recentemente, manifestaçōes contrárias ao revisionismo histórico da imprensa (Toledo, 2009). A disputa pela memória tem na mídia e na imprensa importantes agentes de emissão de opinióes e discursos, que permitem que suas tomadas de posição política sejam dissipadas nas suas coberturas jornalísticas. Os editoriais de $1^{\circ}$ de abril de 1964, em especial de $O$ Globo, são rememorados por sua explícita oposição ao governo de Joáo Goulart e de apoio indiscriminado à ação preventiva das Forças Armadas, por meio da ênfase em um discurso patriótico e nacional, com elementos salvacionistas e cristáos, incitando o agradecimento massivo da população aos militares. $\mathrm{O}$ uso desses editoriais, sem remissão aos seus problemas historiográficos e consolidando-os como "verdade" inquestionável dos fatos, como será argumentado mais a frente, consiste em um problema historiográfico, mas também uma chance para operacionalizaçôes do negacionismo.

Essas reflexóes suscitam a hipótese de que Jair Bolsonaro e o negacionismo - voltado à recusa política e ideológica do golpe de 1964 como o início de uma ditadura - caminham muito próximos, 
especialmente pelo saudosismo e apoio de Bolsonaro a torturadores e violadores de direitos humanos, algo notório em seus discursos sobre a CNV.

\section{A Comissáo Nacional da Verdade frente à memória e o autoritarismo}

A CNV inicialmente foi concebida a partir do Projeto de Lei No 7376/2010, como uma iniciativa de lei da própria Presidência da República, ao final do segundo mandato de Luís Inácio Lula da Silva (2007 - 2010), a ser implementado no governo de sua sucessora, Dilma Rousseff (2011 - 2014). Este projeto, que foi aprovado na íntegra na Câmara dos Deputados e por unanimidade no Senado Federal, mencionava como modelos para o projeto brasileiro as experiências pioneiras da Argentina e da África do Sul (Brasil, 2010a)

Criada pela Lei 12.528/2011, a CNV teria como finalidade, descrita em seu Artigo 10, "examinar e esclarecer as graves violaçóes de direitos humanos praticadas entre 1946 a 1988, a fim de efetivar o direito à memória e à verdade histórica e promover a reconciliação nacional" (Brasil, 2011a). A CNV se insere no panorama da justiça de transição brasileira. Ela permitiria criar uma "estrutura para se confrontar abusos do passado e promoção de maior transformação politica" (Mezarobba, 2009, p. 111). Quanto à memória, ela possibilitaria medidas concretas contra a "política de esquecimento" fomentada pela Anistia de 1979, confrontando os discursos oficiais da ditadura e suscitando uma "batalha pela memória" (Bauer, 2020, 1. 3959 - 3965). Essa batalha identifica a construção de avaliaçôes e hierarquizaçôes de datas e personagens a partir do tempo presente, e seus valores éticos, políticos e morais, o que permite identificar a pertinência dessa relação quanto à Ditadura, a qual "está em constante disputa (...) para se determinar o que será registrado e transmitido às novas geraçôes, em uma conexão entre a memória e a identidade na busca de pertencimento" (Bauer, 2020, 1. 3910). A CNV se diferenciou da visão das Forças Armadas, a qual opera sua memória através de um "relato sobre a ditadura civil-militar brasileira bastante estável desde os acontecimentos da década de 1960, que pouco se alterou" (Bauer, 2020, 1. 3922). Por essas razóes, a CNV encontra seu antípoda nas visōes que defendem os governos militares, ou mesmo, que negam a existência de uma ditadura no Brasil, posicionamentos defendidos por Jair Bolsonaro ao se utilizar da "instrumentalização do passado" (Bauer, 2020, 1. 3871) na defesa de interesses políticos autoritários e contrários à justiça de transiçấo e à memória.

Jair Bolsonaro foi eleito pela primeira vez como Deputado Federal pelo Rio de Janeiro em 1990, acumulando outros seis mandatos e passagem por diversos partidos políticos. Com posicionamentos políticos conservadores, sua base eleitoral primária era inicialmente composta por militares e defensores do regime militar, construindo, ao longo dos anos, discursos pela defesa da segurança pública e falas polêmicas contra os direitos das mulheres e do reconhecimento da diversidade sexual. Dois elementos destacam sua identidade política: sua ancoragem em discursos contrários aos Direitos Humanos, embora permitidos pela pluralidade democrática; $\mathrm{e}$, sua defesa do regime de 1964, o qual è "um pretérito imperfeito, passado que não passou, ponto de partida constante a partir do qual ele se movimentava politicamente" (Pinha 2020, 1. 4573).

A pertinência da defesa de posturas antidemocráticas reforça a noção de que os exercícios autoritários, encarnados nos arbítrios e violaçóes de direitos cometidos no passado não cessaram no tempo presente, demonstrando como o próprio espaço público estaria ainda sujeito a eles. O Estado democrático de direito concebido a partir da Assembleia Constituinte e que culminou na Constituição Federal de 1988, como é sabido, não expurgou totalmente o poder militar das Forças Armadas e das polícias, "enclaves autoritários constitucionalmente sancionados" (Zaverucha, 2010, p. 69). Essas instituições repressivas do passado continuaram habitando, com seus valores e concepçôes, os espaços sociais e as instituiçóes políticas democráticas, de modo a conferir alguma participação nas batalhas pela memória e na definição das diretrizes políticas. A referência a "fendas autoritárias" (Pinha, 2020) permitidas pela Constituição Federal de 1988, no que diz respeito à construção de um consenso democrático e respeito pelas pluralidades políticas, é um forte indício de continuidades supostamente ignoradas pelo pacto democrático. O discurso político de defesa, quase 
apologética, à ditadura civil-militar e ao autoritarismo, embasada pelo negacionismo "sempre estiveram à disposição de quem quisesse mobilizá-lo" (Pinha, 2020, 1. 4672), o que não o torna novidade nos debates sobre o reconhecimento das violaçóes de direitos cometidas pelo Estado brasileiro. Tampouco seu possível expurgo não se inscrevia no processo de conciliação e acomodação do lulismo (Motta, 2018).

\section{Os discursos de oposiçáo de Jair Bolsonaro frente à $\mathrm{CNV}$}

Durante as legislaturas de 2007 - 2010 e 2011 - 2014, o então Deputado Federal pelo Partido Progressista do Rio de Janeiro (PP-RJ), Jair Messias Bolsonaro, atual Presidente da República, se apresentou como uma voz contrária à $\mathrm{CNV}$, apoiando sua argumentação em torno do negacionismo, da construção de uma história alternativa e da defesa da ditadura civil-militar. Compreender as configuraçôes, aproximaçóes e singularidades desses discursos, entre 2010 e 2015, revela os termos em jogo nessa batalha pela memória.

Em relação à pesquisa apresentada, a coleta, classificação e análise discursiva ${ }^{3}$ recorreu a uma formulação metodológica da grounded theory (Glasser \& Strauss, 2006) com o intuito de que os próprios dados direcionassem os elementos a serem categorizados. A amplitude dos temas, decorrentes dos próprios debates entre os parlamentares e de suas formalidades, permitiu com que se identificassem quatro temas chaves: Comissão Nacional da Verdade; Crimes cometidos; Esquerda; Ditadura Civil-Militar. Além disso, identificou-se também outros subtemas, que, ao serem agrupados aos temas chaves, permitiu com que estas fossem tratadas como categorias (Tabela 1):

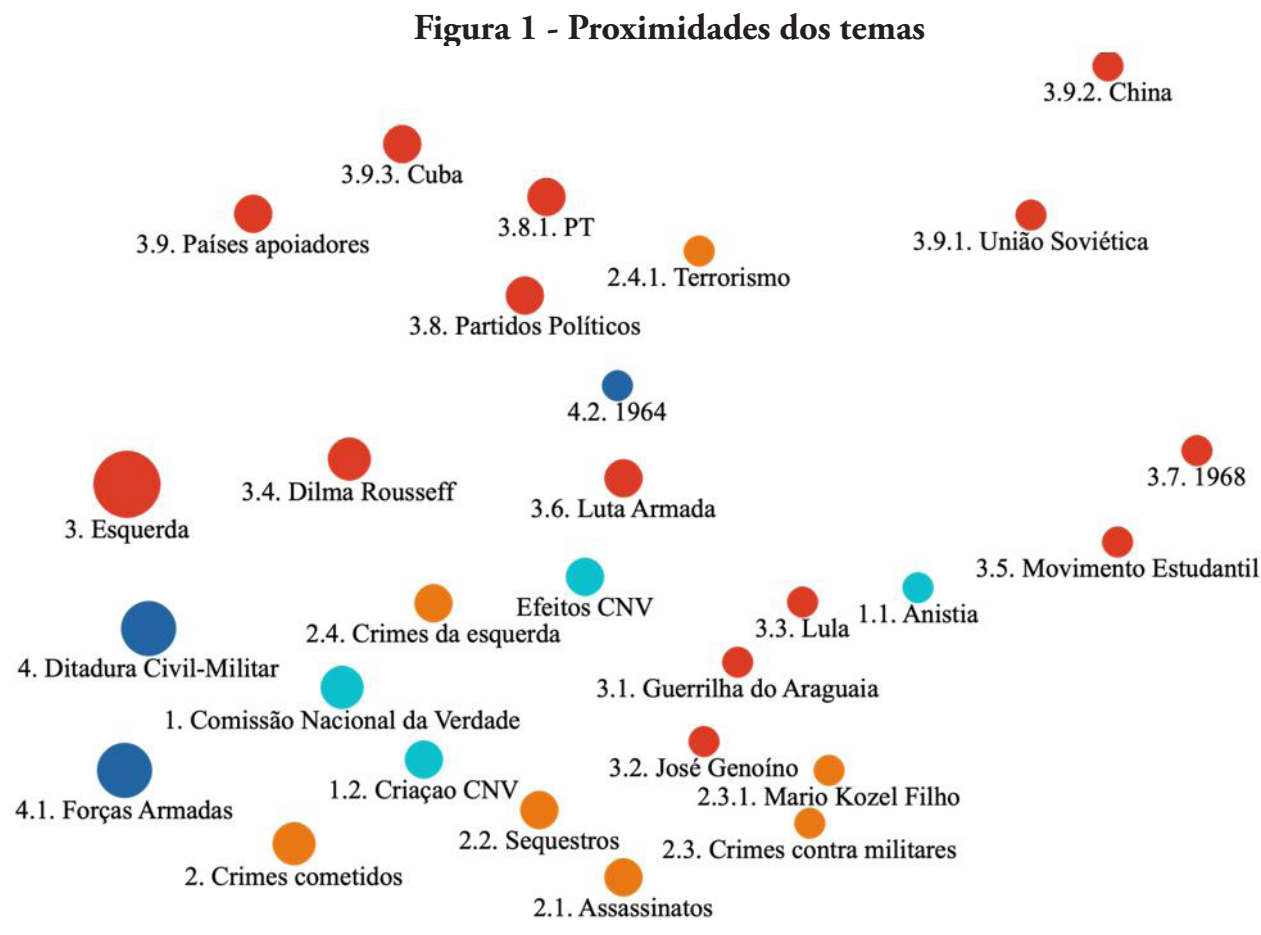

2.4.3. Celso Daniel 3.8.2. $\mathrm{PCDOB}$

2.4.2. Justiçamento

Fonte: Elaboração própria, com base em Brasil (2010b; 2010c; 2011b; 2011c; 2011d; 2011e; 2011f; 2011g; 2012a; 2012b; 2012c; 2012d; 2012e; 2013; 2014). 
Tabela 1 - Matriz de códigos e segmentos

\begin{tabular}{|c|c|c|c|c|}
\hline \multirow{2}{*}{ Código } & \multirow{2}{*}{ Sub-Código 1} & \multirow{2}{*}{ Sub-Código 2} & \multicolumn{2}{|c|}{ Segmentos } \\
\hline & & & $\mathbf{N}$ & $\%$ \\
\hline \multirow[t]{4}{*}{ 1. Comissáo Nacional da Verdade } & & & 50 & 14,58 \\
\hline & 1.1. Anistia & & 9 & 2,62 \\
\hline & 1.2. Criação $\mathrm{CNV}$ & & 25 & 7,29 \\
\hline & 1.3. Efeitos CNV & & 16 & 4,66 \\
\hline \multirow[t]{10}{*}{ 2. Crimes cometidos } & & & 70 & 20,41 \\
\hline & 2.1. Assassinatos & & 17 & 4,96 \\
\hline & 2.2. Sequestros & & 17 & 4,96 \\
\hline & 2.3. Crimes contra militares & & 10 & 2,92 \\
\hline & & 2.3.1. Mario Kozel Filho & 8 & 2,33 \\
\hline & & 2.3.2. Outros & 2 & 0,58 \\
\hline & 2.4. Crimes da Esquerda & & 26 & 7,58 \\
\hline & & 2.4.1. Terrorismo & 14 & 4,08 \\
\hline & & 2.4.2. Justiçamento & 5 & 1,46 \\
\hline & & 2.4.3. Celso Daniel & 7 & 2,04 \\
\hline \multirow[t]{15}{*}{ 3. Esquerda } & & & 143 & 41,69 \\
\hline & 3.1. Guerrilha do Araguaia & & 10 & 2,92 \\
\hline & 3.2. José Genoíno & & 10 & 2,92 \\
\hline & 3.3. Lula & & 6 & 1,75 \\
\hline & 3.4. Dilma Rousseff & & 42 & 12,24 \\
\hline & 3.5. Movimento Estudantil & & 2 & 0,58 \\
\hline & 3.6. Luta Armada & & 17 & 4,96 \\
\hline & 3.7 .1968 & & 2 & 0,58 \\
\hline & 3.8. Partidos Políticos & & 21 & 6,12 \\
\hline & & 3.8.1. PT & 20 & 5,83 \\
\hline & & 3.8.2. PCDOB & 1 & 0,29 \\
\hline & 3.9. Países apoiadores & & 33 & 9,62 \\
\hline & & 3.9.1. União Soviética & 3 & 0,87 \\
\hline & & 3.9.2. China & 3 & 0,87 \\
\hline & & 3.9.3. Cuba & 27 & 7,87 \\
\hline \multirow[t]{3}{*}{ 4. Ditadura Civil-Militar } & & & 80 & 23,32 \\
\hline & 4.1. Forças Armadas & & 66 & 19,24 \\
\hline & 4.2 .1964 & & 14 & 4,08 \\
\hline TOTAL & & & 343 & 100,00 \\
\hline
\end{tabular}

Fonte: Elaboração própria, com base em Brasil (2010b; 2010c; 2011b; 2011c; 2011d; 2011e; 2011f; 2011g; 2012a; 2012b; 2012c; 2012d; 2012e; 2013; 2014).

Para tanto, esse método suscitou a observação de proximidades (Figura 1) e intersecções (Figura 2) desse universo temático, as quais ressaltam a polarização entre o passado (ditadura civil-militar) e o presente (esquerda), permitindo identificar, de fato, o que estaria em jogo e quais as estratégias de interpretação histórica que estavam sendo realizadas. Uma consideração inicial permite constatarmos algumas desconexóes entre temas bastante centrais na historiografia sobre a ditadura civil-militar, como, por exemplo, o afastamento das relaçóes entre a Guerrilha do Araguaia e o PCDOB, a presença de uma fala marcante acerca do entâo Deputado José Genoíno (PT), ou então, a relação de Cuba com a luta armada, a pouca importância dada ao movimento estudantil e a menção de crimes políticos ocorridos posteriormente ao período ditatorial, como no caso do Prefeito de Santo André, Celso Daniel, assassinado em 2001. No entanto, a esquerda é vista como o 


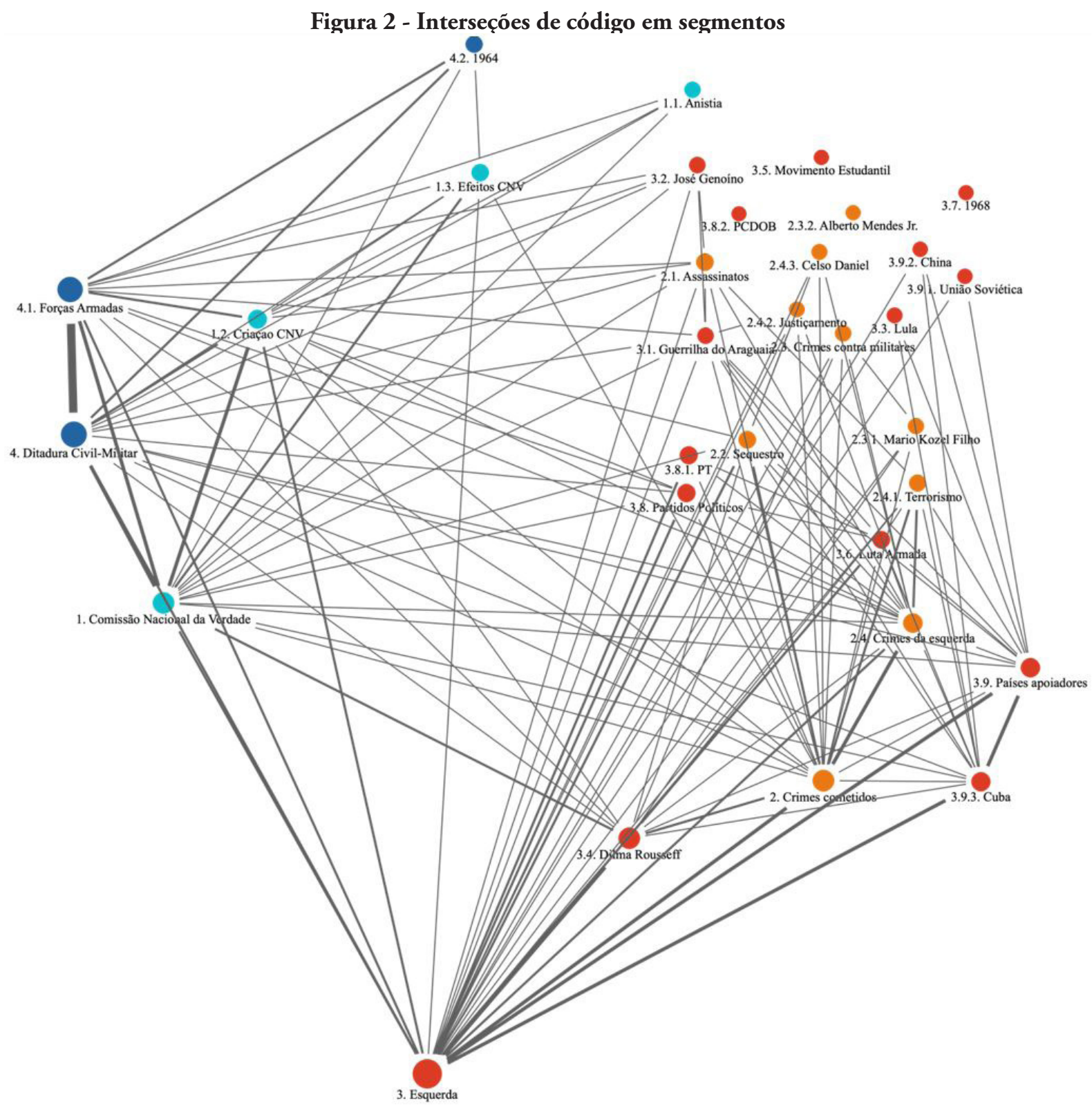

Fonte: Elaboração própria, com base em Brasil (2010b; 2010c; 2011b; 2011c; 2011d; 2011e; 2011f; 2011g; 2012a; 2012b; 2012c; 2012d; 2012e; 2013; 2014).

elemento de polarização, imbricada com a referência de crimes cometidos no passado e no presente.

\section{O revanchismo como "a verdade" da}

\section{Comissáo}

Para Bolsonaro, a criaçáo da CNV seria uma espécie de "revanchismo" em relação aos feitos dos militares no passado. Ao afirmar que "os perdedores de 1964 hoje estão no Poder, na busca do seu caminho, de um regime não aceito pelo povo brasileiro" (Brasil, 2012c, p. 9543), ou mesmo que a Comissão "quer[ia] contar a história como melhor lhe apraz, e não como ela 
aconteceu de verdade" (Brasil, 2010b, p. 25083), seu discurso entoou elementos do negacionismo histórico.

$\mathrm{O}$ início da oposição contra a criação da CNV data de 2010, período em que se debatia o projeto de lei enviado por parlamentares e membros da sociedade civil ao Congresso Nacional. Para o entáo Deputado, a CNV seria unilateral por não apurar crimes cometidos pela esquerda, os quais poderiam ser considerados até mesmo mais nefastos do que os eventuais crimes cometidos pelos militares, como "sequestro e justiçamento, largamente usados pelo PCdoB no Araguaia” (Brasil, 2010b, p. 25083). No intento de respaldar tal argumento, e por causa da indicaçáo dos membros pela Presidência da República, considerava que a Comissão não teria um justo compromisso com a verdade, comprometendo seus resultados.

Sob a ótica de Bolsonaro, o principal efeito da CNV seria a autorizaçáo da prisão de militares fato que não existia no projeto de lei e que tampouco esteve presente na Lei No 12.528. As indicaçôes dos membros da CNV, fato descrito na Lei No 12.528 , foram interpretadas como uma tentativa do Governo Federal de realizar uma escolha parcial, de modo a estabelecer um "tribunal de exceção para prender militares"(Brasil, 2011b, p. 50875), ou seja, colocando outro procedimento legislativo em contraposição ao que já havia sido acordado pela Lei da Anistia, causando celeumas com os militares. Nos discursos, a Lei da Anistia passaria a se conflitar com a CNV, já que, na interpretaçấo do ex-Deputado, o Artigo 4. ${ }^{\circ}$ da CNV "desborda a Lei da Anistia e permite a prisāo de militares" (Brasil, 2011e, p. 2721). No entanto, o Artigo 4..$^{\circ}$, em seus $₫ 3$ e $\$ 4$ é taxativo quanto à náo prisão de militares, apresentando apenas o dever de colaboração dos servidores públicos e a ausência, nas atividades da $\mathrm{CNV}$, de caráter jurisdicional ou persecutório (Brasil, 2011a).

A pertinência do argumento favorável à Lei da Anistia corrobora com as análises acerca da imposição do esquecimento e do silenciamento, perante uma inviolabilidade desta lei. Porém, essa intenção não é explícita, sendo tratada como um aparente conflito da $\mathrm{CNV}$ com a Lei da Anistia, o que náo se configura na prática, tendo em vista a anterior garantia de anistia aos militares, e que a CNV, por ser uma lei ordinária, tampouco teria poderes para revogar a Lei da Anistia.
Sob uma falsa polêmica do ordenamento jurídico, os termos postulados por Bolsonaro induzem a uma inversão entre vítima e algoz, cabendo manter aos militares violadores sua inimputabilidade.

Os termos do "revanchismo" apregoado pelo ex-Deputado inferiam que a CNV divulgaria uma história sem compromisso real com a verdade, querendo reconstruir a História do Brasil a partir de seus interesses: atribuindo heroísmo à esquerda $\mathrm{e}$ retirando o protagonismo dos militares. Essa história reescrita possibilitaria "reabrir feridas" (Brasil, 2011b, p. 50875), restabelecendo um conflito do passado ou, ainda, apagar os feitos e atos de ex-participantes da luta armada. A interpretaçáo manifesta do exDeputado opóe, sobremaneira, duas narrativas: uma verdadeira, proveniente do heroísmo dos militares, e uma falsa, que a CNV iria escrever. Para Bolsonaro, os militares seriam vítimas de um ataque deliberado do governo de Dilma Rousseff, pois suas açōes no passado consolidaram a imagem de um "último obstáculo" à tomada de poder das forças comunistas (Brasil, 2014, p. 25). Assim, o sentimento salvacionista era reiterado contra as possibilidades de reescrita da história pela Comissão, alertando para uma tentativa de manipulação da história pelo PT.

A tônica do discurso de Bolsonaro foi construída com a ideia de que a CNV serviria tanto para "bumilhar os militares, que tantos serviços prestaram ao País desde a criação do Exército, em especial em 1964" (Brasil, 2012c, p. 9543), quanto para discordar da história oficial e "verdadeira", que foi divulgada pelos jornais de 1964. Aqui reside, portanto, um elemento-chave dos argumentos do ex-Deputado, qual seja considerar que os editoriais de diversos jornais da época, por apoiarem as açóes das Forças Armadas, relataram a "verdade", como se realmente tudo houvesse sucedido da forma como se narrou naquelas mídias jornalísticas - naturalmente sem oferecer nenhum crivo crítico ao uso das fontes. Essa operacionalizaçáo discursiva do negacionismo considera que tais fontes são idôneas e referenciadas de acordo com uma interpretação excessivamente literal, a qual não questiona os interesses e as ideologias contidas nesses editoriais, mas, pelo contrário, é condescendente quanto aos conteúdos dos editoriais e as teses da intervençáo preventiva, denotando clara manipulaçáo factual ao 
afirmar que "toda a imprensa apoiou aquele momento em que as Forças Armadas estiveram à frente, para que o regime fosse mudado" (Brasil, 2012c, p. 9543). A reflexão sustentada pelo ex-Deputado era a de que a CNV teria como objetivo a reconstrução da história, através de valores revanchistas, invertendo vítimas e algozes, desconsiderando o papel heroico dos militares e impondo uma falsa "verdade", diferente daquela atestada pelos jornais de 1964 e favorável aos militares.

Nesse ínterim, é percebido que os temas CNV (código), Criação da CNV e Efeitos da CNV (subcódigos) se relacionam com a presença histórica da esquerda brasileira (como identificado na Figura $1 \mathrm{e}$ na Figura 2) e à disputa de sua memória, já que a desconfiança para com a CNV indica também a tendência de construção de uma história alternativa, pautada pela excessiva culpabilidade da esquerda pelos rumos da política brasileira. A oposição entre verdade e mentira, a despeito de quaisquer sentidos filosóficos e sociológicos, compõe uma interpretação naturalista e dicotômica, a qual sugere uma polarização no discurso político, entre o passado e o presente, enfatizando uma consequência alarmista da Comissão, que desmontaria os posteriores consensos legitimadores dos atos políticos golpistas de 1964 .

Ainda, Bolsonaro manifestou que as Forças Armadas haviam esboçado alguma preocupação, de modo a se sentirem acuadas pela criação da CNV. No entanto, ao afirmar que os militares se posicionaram ao lado dos democratas — neste caso, dos que apoiaram os militares e que também queriam a verdade - evoca que essa verdade deveria ser diferente daquela investigada pela Comissão. Essas preocupaçóes novamente se referem à prisão de militares, por tipificar seus crimes e a reconstrução histórica que poderia ocorrer através de sua imposição do relatório "junto aos livros do MEC para se fazer uma nova História moderna brasileira, tendo os militares como bandidos nesse periodo de 1964 a 1986" (Brasil, 2011f, p. 53007).

\section{Os crimes cometidos pela luta armada}

O núcleo argumentativo de Bolsonaro contra a CNV diz menos respeito às Forças Armadas e ao seu papel em 1964 e muito mais à esquerda e à luta armada, denunciando supostos crimes cometidos pela esquerda. Há aqui uma forte articulação entre o negacionismo e a construção de uma história alternativa, legitimando um ataque político contra as esquerdas, mediante a apuração de seus crimes.

A Guerrilha do Araguaia foi descrita como um projeto político de José Genoino, "um homem que tentou criar uma Farc no coração do Brasil” (Brasil, 2012d, p. 33206) e que havia praticado crimes de sequestro e justiçamento, matando mais de 11 pessoas, crimes estes que não seriam apurados pela $\mathrm{CNV}$ (Brasil, 2010c, p. 32351). Esse justiçamento seria o resultado de um processo em que o "jovem (...) aliciado na universidade, ia para o Araguaia pensando em liberdade, iludido, quando pensava em sair, (...) era simplesmente executado, e seu corpo sumia"(Brasil, 2010c, p. 32351)

Nos discursos apurados, apenas um caso específico foi citado como exemplo de justiçamento, o caso do mateiro João Pereira. A narrativa empreendida por Bolsonaro pressupóe o justiçamento em um caso hipotético, de deserção do guerrilheiro Pedro Albuquerque. O justiçamento de João Pereira consta propriamente no Relatório Arroyo, embora haja poucos detalhes e destoe da narrativa dos guerrilheiros em estabelecer, desde 1966, relaçóes de solidariedade, de aproximação e de cooperação com as comunidades locais da região do Araguaia. Porém, os sentidos atribuídos ao justiçamento pouco dependem das condiçóes e dos fatos, pois são tomados como uma prática corriqueira dos guerrilheiros, apagando registros de torturas, prisóes e desaparecimentos forçados coordenados pelo Estado contra os guerrilheiros. Paralelamente, o mesmo argumento de justiçamento no Araguaia já havia sido apresentado pelo coronel Carlos Alberto Brilhante Ustra, que sugeria a presença de tribunais revolucionários realizados pelos guerrilheiros, responsáveis pelas mortes de Rosalindo de Souza (Mundico), e dos moradores locais Osmar, Pedro Mineiro e João Mateiro. Os crimes supostamente cometidos e admitidos pelos próprios guerrilheiros são vistos como característicos de sua ideologia política e constituem elemento chave na construção do negacionismo, pois não apenas equipara os "dois demônios", mas decreta que a violência e o golpismo partiram da esquerda, demandando uma ação preventiva dos militares. 
Há diversas versóes contrapostas para muitos desses crimes: aquelas oferecidas pelos militares de modo a forjar situaçóes de violência, versōes dadas por parentes e familiares das vítimas, de testemunhas, entre outras. Os relatórios e dossiês históricos trabalham diretamente com as fontes escritas e orais - em um vasto trabalho de historiadores, arquivistas e cientistas sociais - , com o propósito de desvendar os acontecimentos e suas interpretaçôes, mobilizando a memória coletiva e individual daquele período. Por outro lado, assim como a história apresentada por Bolsonaro é imprecisa e descontextualizada, o escrito de Ustra é abundante na imprecisão de fontes e de relatos, mesmo que suas referências citadas sejam provenientes de arquivos pessoais (e não públicos) dos próprios militares, ou ainda, fontes da imprensa escrita ou sites e blogs de procedência suspeita.

A despeito de qualquer tentativa de oferecer novas versōes ao caso supracitado - o que ultrapassa os interesses do presente artigo - é importante mencionar um elemento fulcral presente nesse negacionismo: o silenciamento das fontes, mediante a tentativa de superposição de relatos e versões, ou conjeturando a revelaçáo de outras fontes desconhecidas e "verdadeiras" ao grande público. Isso permite suposiçôes, manipulaçōes e inferências inscritas na forma que melhor se adeque aos interesses do emissor e, fundamentalmente, às suas tendências ideológicas e políticas. A manipulação dos acontecimentos da Guerrilha do Araguaia tem como objetivo contar uma história alternativa, de maior impacto no discurso político e comprometida com uma verdade unilateral assentada nas próprias crenças morais dos apologistas da ditadura quanto ao caráter violento e antidemocrático da esquerda, ignorando as apuraçóes técnicas, históricas e científicas que possam existir. Por ser um dos casos de maior conhecimento e destaque da repressão brasileira, os crimes dos agentes do Estado foram amplamente apurados, o que implicou na condenação e adoção de medidas de reparaçáo aos familiares de mortos e desaparecidos políticos do Araguaia (Corte Interamericana de Direitos Humanos, 2010). Uma narrativa de supostos justiçamentos no Araguaia evidencia como o negacionismo se utiliza de casos concretos presentes nos rincôes dos fatos pouco estudados pela historiografia, ou pouco conhecidos do público em geral, e nas lacunas da memória e dos silenciamentos permitidos pelas incompletudes da justiça de transição brasileira, dando-lhes uma roupagem mais adequada ao momento político.

O tema dos crimes cometidos no Araguaia está interligado com a aproximação da esquerda brasileira com Cuba e Fidel Castro, fato enfatizado no discurso ao afirmar "militares evitaram que nos transformássemos em uma Cuba" (Brasil, 2011c, p. 5450). O caso cubano é tratado como um modelo, seja de conduta ética para os militantes de esquerda, seja de treinamento militar para as guerrilhas e seu respectivo financiamento: quanto ao primeiro, a mençáo se faz em torno de afirmaçóes elogiosas de Lula e de Dilma a Fidel Castro (Brasil, 2012e, p. 17333); sobre o segundo, Cuba é descrito como o país que ofereceu "treinamento militar" aos brasileiros em diversos momentos, como a Guerrilha da Serra do Caparaó e, principalmente, na Guerrilha do Araguaia (Brasil, 2011g, p. 53041). As aproximaçóes entre guerrilheiros e Cuba são sustentadas por um argumento que oscila entre um apoio autônomo de Cuba e um apoio sustentado pela União Soviética via Cuba (Brasil, 2014, p. 25), apontando também, ainda que residualmente, os interesses da China e da Coreia do Norte nas guerrilhas. Os "cursos" realizados pelos guerrilheiros são descritos como o aprendizado "de como torturar, de como sabotar, de terrorismo, e vieram aqui ao Brasil falar que combatiam uma tal de ditadura" (Brasil, 2011g, p. 53041), inferindo que o regime cubano tinha interesse em "implantar a sua ditadura" (Brasil, 2013, p. 11968), não oferecendo nenhuma contribuição para a democracia brasileira.

Outros episódios da luta armada são referidos pela participação de personagens como Dilma Rousseff (VAR-Palmares), Franklin Martins (ALN), Carlos Lamarca (VPR) e Carlos Franklin Paixão de Araújo (VAR-Palmares). ${ }^{4}$ Este último, que havia sido casado com Dilma Rousseff, é mencionado em razão de seu depoimento em um capítulo da novela Amor e Revolução, do SBT, exibida em 2011, no qual, segundo Bolsonaro, "conta que ele e Dilma assaltavam carros de transporte de gêneros na Baixada Fluminense para dar ao povo, como ação humanitária" (Brasil, 2012e, p. 17333). A disposiçáo violenta dos grupos da luta armada constitui, neste discurso, a principal prova 
de que os militares operariam a contenção da ameaça comunista, embora se saliente o anacronismo do argumento da tomada de poder de modo preventivo em 1964, contrastando com os episódios da luta armada que surgem somente a partir de 1968. Prova dessa manipulação temporal e imprecisão é observada nas Figuras 1 e 2, conforme temas como o PCDOB, partido que conduziu a Guerrilha do Araguaia, ou o movimento estudantil, enquanto organização que promoveu diversos quadros para as lutas armadas, são tratados residualmente, revelando a inconsistência causal desse argumento.

A possível participação de Dilma Rousseff, quando ainda militava na VAR-Palmares, é atribuída ao episódio do assalto ao cofre do ex-Governador de São Paulo, Adhemar de Barros, ocorrido em 1969 no Rio de Janeiro, ${ }^{5}$ não sendo este o único crime da esquerda que não seria apurado pela CNV (Brasil, 2012a, p. 6011). Há outros crimes referidos por Bolsonaro, os quais foram supostamente praticados contra militares. O primeiro é a morte do soldado Mário Kozel Filho em um atentado contra o Quartel General do IIo Exército, em São Paulo, no dia 26 de junho de 1968, que argumenta veladamente por uma suposta participação de Dilma (Brasil, 2011e, p. 2721; 2011g, p. 53041; 2012a, p. 5819; 2013, p. 11968). Esse atentado, que ocorreu no mesmo dia da Passeata dos Cem Mil no Rio de Janeiro, causou efeitos nos discursos oficiais, pois, assim, em contraposição à morte do estudante Edson Luiz, "a ditadura tinha o seu jovem soldado-mártir para exibir para a sociedade" (Napolitano, 2016, p. 124), além de supor a existência de um "plano geral de subversão" que justificaria medidas de exceção (Valle, 2008, p. 131). O segundo crime mencionado é a morte do Tenente Alberto Mendes Júnior, executado por guerrilheiros que fugiram da coluna de Carlos Lamarca, em Eldorado Paulista, em 8 de maio de 1970 (Brasil, 2010c, p. 32351; 2011d, p. 1342). ${ }^{6}$ Bolsonaro afirma que esses crimes seriam comprometedores de Dilma e da esquerda, e, por isso, não seriam apurados pela $\mathrm{CNV}$.

Por fim, um crime mencionado exaustivamente por Bolsonaro, e que ultrapassa o período da ditadura, é o assassinato do Prefeito de Santo André, Celso Daniel, ocorrido em janeiro de 2002. Para o ex-deputado, "o sequestro, a tortura e a execução do
Celso Daniel não interessam a vocês", de modo que seria "permitida a corrupçáo seletiva e [que] vale[ria] a pena justiçar e executar um colega por uma causa maior, que era a eleição de Lula" (Brasil, 2011g, p. 53041). Aqui torna-se clara a instrumentalização da história no tempo presente, de acordo com o contexto político da década de 2010 , dado o início das apuraçóes de envolvimento do PT em casos de corrupção. Essa narrativa, contudo, não se fez de modo isolado, mas em alguns momentos, foi seguida pela suposição de que Celso Daniel foi torturado por estar prestes a denunciar casos de corrupçáo do PT mediante um possível dossiê que "detona[ria] o esquema de corrupçáo que financiava o partido" (Brasil, 2010c, p. 32351). Esse caso foi permeado por várias polêmicas em seu desfecho e que continua sem muitas respostas. Por isso, a instrumentalização e manipulação desse fato induzem ao entendimento de linhas de continuidade entre os crimes cometidos pela esquerda no passado e no presente, desviando o foco dos crimes atribuídos aos militares e ao Estado. Entretanto, esse caso parece ter um estatuto de brecha para a propagação da ideia de impunidade para a esquerda, suscitando um negacionismo pautado na falsa evidência factual. ${ }^{7}$ Do ponto de vista retórico, a menção a esse crime busca compor relaçôes entre o PT e a sua possível complacência para com os delitos da esquerda na ditadura civil-militar, ratificando a suspeita de continuidade no cometimento desses crimes no tempo presente.

\section{A imprensa como "fonte" do negacionismo}

As fontes que fundamentam o negacionismo do discurso de Bolsonaro não são mantidas incógnitas: mais de uma vez o ex-deputado mencionou as manchetes e editoriais dos jornais de 1964, como O Globo, Jornal do Brasil, O Dia, Correio da Manhã e Tribuna da Imprensa (Brasil, 2011c, p. 5450; 2012c, p. 9543; 2012d, p. 33206; 2012e, p. 17333), argumentando que essa seria a verdadeira história, diferentemente daquele que a CNV almejava escrever. Estas fontes lhe permite uma conclusão unívoca: a tomada de poder pelas Forças Armadas foi "a prova inconteste de que eles [os comunistas] se preparavam para tomar o poder pela força antes de 1964" (Brasil, 2012e, p. 17333). 
$\mathrm{O}$ argumento de golpe preventivo foi difundido na convergência entre a imprensa e a teoria da guerra revolucionária. Porém, ao relativizar o papel da imprensa e de seus interesses políticos, Bolsonaro superestima e mitifica a versão apresentada nos editoriais de 1964 , como sendo "a única" versão possível, sendo que essa é "uma” versão, favorável ao golpe. Bolsonaro credita a 1964 aos interesses da população, visto a não aceitação popular da legitimidade de João Goulart como Presidente, e que, dessa forma, após Ranieri Mazzili ter assumido o cargo como Presidente Interino, seu mandato foi cassado pelo Plenário da

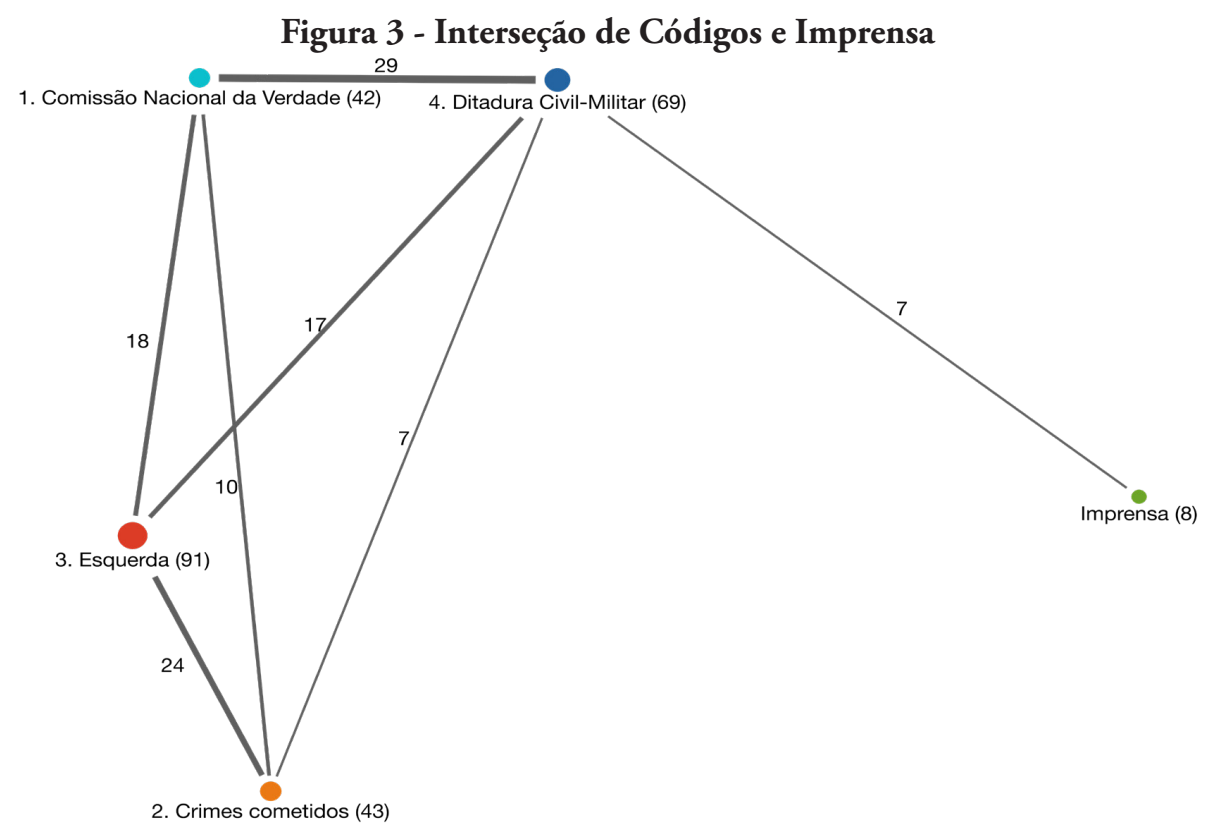

Fonte: Elaboração própria, com base em Brasil (2010b; 2010c; 2011b; 2011c; 2011d; 2011e; 2011f; 2011g; 2012a; 2012b; 2012c; 2012d; 2012e; 2013; 2014).

Figura 4: Sobreposição de Códigos e Imprensa

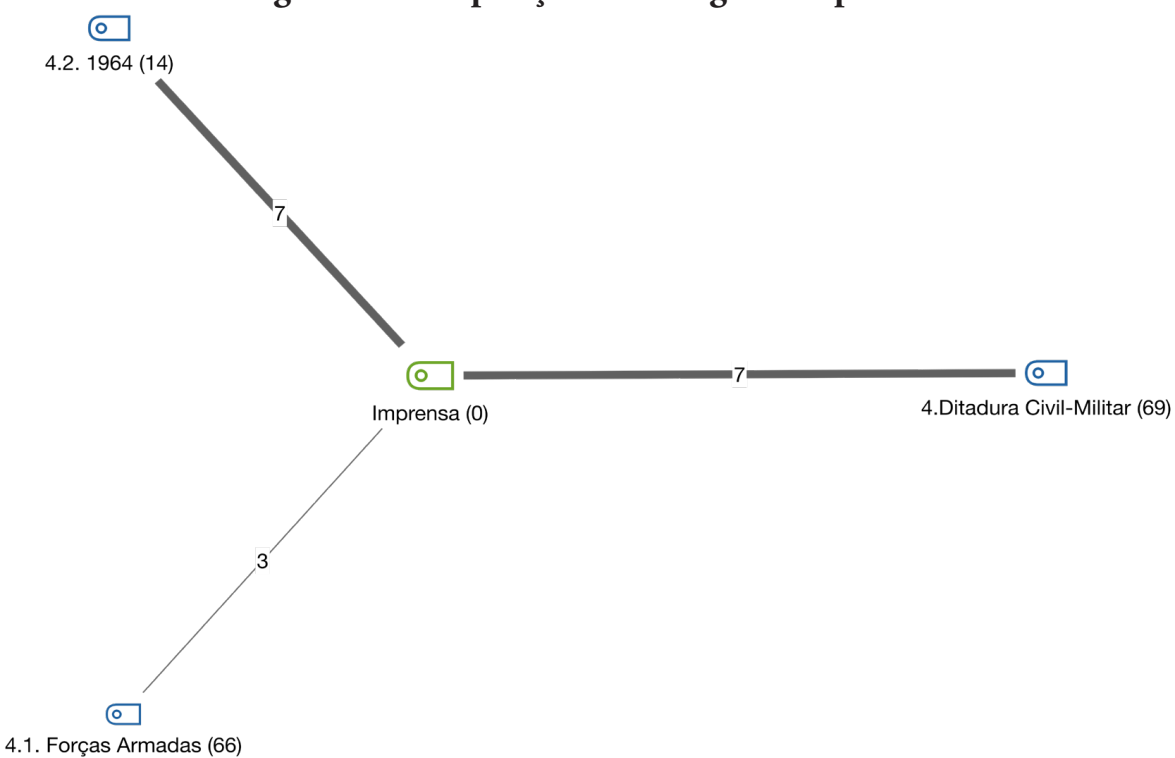

Fonte: Elaboração própria, com base em Brasil (2010b; 2010c; 2011b; 2011c; 2011d; 2011e; 2011f; 2011g; 2012a; 2012b; 2012c; 2012d; 2012e; 2013; 2014). 


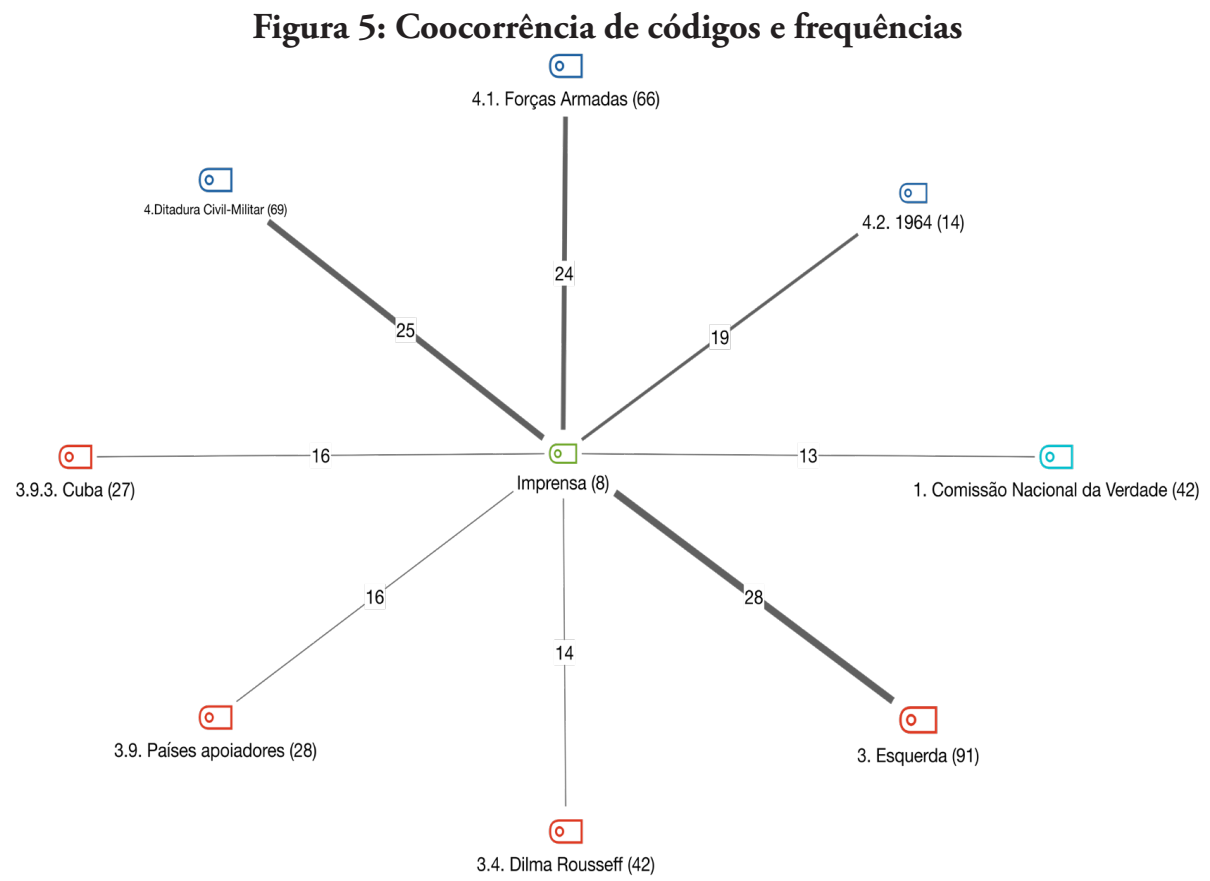

Fonte: Elaboração própria, com base em Brasil (2010b; 2010c; 2011b; 2011c; 2011d; 2011e; 2011f; 2011g; 2012a; 2012b; 2012c; 2012d; 2012e; 2013; 2014).

Câmara dos Deputados, elegendo Castello Branco alguns dias depois, o que não significaria um golpe. ${ }^{8}$

A imprensa como "fonte" do negacionismo presente nos discursos de Bolsonaro pode ser verificado nas Figuras 3 e 4:

$\mathrm{O}$ que se evidencia aqui é que a sustentaçáo argumentativa da ditadura civil-militar é dada pela referência à imprensa, praticamente em oposição à esquerda, em termos de suas mençôes (Figura 4). Além disso, o tema específico a ser trabalhado é a reinterpretaçáo do golpe de 1964, em detrimento de elementos que dissessem respeito às Forças Armadas e seus interesses (Figura 5), apesar de haver, no conjunto dos discursos, muito mais referências a elas do que a 1964. Porém, é significativo mencionar que a visão de 1964 apresentada é mediada pela citação dos editoriais e das capas de jornais de 1964. Portanto, o negacionismo defendido por Bolsonaro não apenas é construído sobre uma simples negação do golpe de 1964, mas da negação do golpe de 1964 a partir da versão que a imprensa forneceu em 1964, o que traz muito mais similaridades com um discurso midiático do negacionismo do que uma construção com fundamentos teóricos que partem do revisionismo da historiografia acadêmica. A entrada desse discurso na esfera pública, na construçáo de uma linguagem política negacionista, fornece elementos de fácil adesão, em especial, para as visóes da direita e extrema-direita, em um contexto em que a memória coletiva ainda se encontra interrompida e que a ditadura continua sendo dada como inexistente.

\section{Conclusáo}

A vertente brasileira do negacionismo transita em torno de três elementos: do do suposto revanchismo imputado à esquerda" descrito nas tentativas de apuraçẫo da memória; da acusação de que a esquerda e a luta armada eram os verdadeiros responsáveis por crimes cometidos no passado e de sua continuidade no presente; e de um negacionismo pautado nas versóes pouco críveis dos editoriais e de algumas visóes da imprensa sobre 1964. Estes elementos possibilitam uma manipulação das informaçôes e da construção de histórias alternativas, diferentes dos fatos apurados por historiadores, especialistas, organizaçóes jurídicas internacionais, entre outros, argumentando pela 
existência de uma "verdade" privada, conhecida por poucos e ainda ausente do debate público. A partir da análise desse momento, identifica-se elementos que são fundamentais para a alteração do passado, como crimes não completamente apurados e suas relaçóes com grupos políticos da esquerda, ainda que tal narrativa sirva para dar corpo a uma defesa "cega" da ditadura, das infraçôes de direitos humanos e que procuram expurgar, a todo momento, a construção de uma memória coletiva sobre a ditadura militar.

A CNV, ao ser proposta e implementada, desestabilizou a segurança do silenciamento das histórias de resistência e das políticas de memória que o governo brasileiro deveria encampar como medidas para efetivar a transição democrática $\mathrm{e}$ sua justiça de transição. A tônica dos discursos de Bolsonaro considerou que a $\mathrm{CNV}$ era uma retaliação política aos militares, um revanchismo das forças políticas de esquerda, ao invés de revelar e apurar os crimes cometidos por seus próprios quadros, os quais tinham interesse de estabelecer o comunismo no Brasil. Tal versão embasa o lado de defesa dos militares e do autoritarismo contra a violência imposta pela esquerda nessa batalha pela memória, não havendo sido depurada pela justiça de transição e permanecendo nos debates políticos em defesa do autoritarismo no tempo presente, dada a fragilidade da inscrição da ditadura na memória coletiva. $\mathrm{O}$ questionamento sobre a aceitação dessas teses revela elementos de sua permissividade na sociedade, já que nunca houve seu total afastamento, permanecendo em aberto as fissuras autoritárias.

A alusão aos crimes da esquerda no período militar é algo que ultrapassa o jogo retórico, funcionando como uma linguagem política derivada do negacionismo, que busca ser atrativa aos opositores do PT e das esquerdas, estando salientada na ideia de que a violência era proveniente da luta armada e não dos militares. O cometimento de crimes por parte dos governos militares que são amplamente atestados nas fontes históricas é ocultado, transparecendo uma única preocupaçáo em torno do discurso de um suposto "mal maior": a possível tomada de poder dos comunistas. Por isso, compreende-se que a associaçấo direta entre a esquerda e diversos crimes não é uma especificidade da luta armada ou a casos particulares: essa construçáo pode ser incorporada no trato do tempo presente, de modo a sugerir, por linhas sinuosas, a necessidade de um projeto político que possa propor a criminalizaçáo da esquerda, ou o que se possa supor que ela seja. Aqui reside, portanto, a perversidade desse negacionismo.

\section{AGRADECIMENTOS}

Agradeço a Professora Maria Ribeiro do Valle, ao João Felipe Lopes Rampim e ao Paulo Geovane e Silva pelas leituras e correçôes dos primeiros manuscritos. Agradeço também aos pareceristas da RBCS pelas substantivas sugestôes apresentadas ao artigo. O presente trabalho foi realizado a partir do financiamento do Programa Nacional de Pós-Doutorado (PNPD/CAPES) - Código de Financiamento 001.

\section{Notas}

1 Utilizamos o termo Ditadura Civil-Militar enfatizando, como o faz Fico (2004), a participação dos civis (elites e classes médias) na elaboração do golpe de 1964 e a conduçấo de um governo ditatorial pelos militares, articulando condicionantes estruturais e processos conjunturais. $\mathrm{Na}$ análise dos discursos utilizam-se relaçôes genéricas: Regime Militar (referências gerais, esparsas e específicas sobre o período); Forças Armadas (grupo específico), Golpe de 1964 (processo de tomada de poder).

2 Tanto Ustra como Olavo de Carvalho contemplam as referências ideológicas do Governo Bolsonaro (20192022).

3 Utilizamos MAXQDA 2020 (VERBI Software, 2019) para a análise de dados.

4 Neste depoimento, Carlos Araújo conta quais eram as açóes de seu grupo armado, a VAR-Palmares: expropriaçôes de bancos para compra de armas, açôes em quartéis, ações sociais de roubo de cargas de caminhão e distribuição das mercadorias em favelas, além de se referir ao idealismo de suas atitudes, mas sem negar o orgulho de sua participação. Em outro depoimento para a mesma novela, Carlos refere-se a alguns dos fatos relativos à prisão de Dilma Rousseff, a tortura sofrida na Operaçấo Bandeirantes, a sua condução ao Dops, a condenação de três anos e ao cumprimento da prisão.

5 Sendo ainda escassas as fontes sobre esse episódio, ver Cardoso (2011). 
6 Um levantamento e análise das controvérsias nesse caso, o que inclui uma suposta presença de Bolsonaro nessa captura, ainda quando adolescente, foram apresentadas posteriormente por Carvalho (2019).

7 O documentário Quem mandou matar Celso Daniel? (2019), da plataforma virtual conservadora Brasil Paralelo é um exemplo disso, conforme utiliza-se de depoimentos de envolvidos nos casos do Mensalão e na Operação Lava-Jato, para inferir que Lula foi um mandante desse crime. É importante mencionar que essa plataforma propaga o argumento do negacionismo histórico de 1964, reiterando argumentos da ameaça comunista, do apoio popular dos militares e de que a luta armada desejava implantar uma ditadura do proletariado (Brasil Paralelo, 2018). Sobre os usos do passado e as intencionalidades no tempo presente, ver o debate sobre o historiador Marco Antônio Villa, em Bauer e Nicolazzi (2016).

8 O Projeto de Resolução 4/2013 anulou a sessão do Senado que declarou vaga a cadeira da Presidência da República ocupada por João Goulart. Nessa votação, Jair Bolsonaro foi o único a se manifestar contrariamente, descrevendo esse ato como "infantil" e "stalinista" (Mendanha e Vilar, 2013).

\section{BIBLIOGRAFIA}

BAUER, Caroline, NICOLAZZI, Fernando. (2016). "O Historiador e o Falsário: Usos públicos do passado e alguns marcos da cultura histórica contemporânea”. Varia Historia, Belo Horizonte, 32, 60: $807-835$.

BAUER, Caroline (2020), "Usos do passado da ditadura brasileira em manifestaçôes públicas de Jair Bolsonaro”. in V. Araújo, B. Klem, M. Pereira (org.), Do fake ao fato: Des(atualizando) Bolsonaro, Vitória, Editora Milfontes: 183-204 (3865 - 4485, Kindle Version).

BIROLI, Flávia. (2009), "Representaçóes do golpe de 1964 e da ditadura na mídia - sentidos e silenciamentos na atribuição de papéis à imprensa, 1984 - 2004”. Varia Historia, Belo Horizonte, 25, 41: $269-291$.

BRASIL. (2010a), Projeto de Lei No 7376/2010. Disponível em: https://www.camara.leg.br/proposicoesWeb/ fichadetramitacao?idProposicao $=478193$, consultado em 12 jul. 2020.
BRASIL. Congresso Nacional. Câmara dos Deputados. (2010b), Grande Expediente, Diário da Câmara dos Deputados, LXV, 83, 2 Jun: 25083.

BRASIL. Congresso Nacional. Câmara dos Deputados. (2010c), Pequeno Expediente. Diário da Câmara dos Deputados, LXV, 105, 8 jul: 32351.

BRASIL. (2011a), Lei No 12.528, de 18 de novembro de 2011. Disponível em: http://www.planalto.gov. br/ccivil_03/_Ato2011-2014/2011/Lei/L12528. htm, Consultado em 12 jul. 2020

BRASIL. Congresso Nacional. Câmara dos Deputados. (2011b), Breves Comunicaçôes. Diário da Câmara dos Deputados, LXVI, 161, 16 set: 50875.

BRASIL. Congresso Nacional. Câmara dos Deputados. (2011c), Grande Expediente. Diário da Câmara dos Deputados, LXVI, 021, 10 fev: 5450.

BRASIL. Congresso Nacional. Câmara dos Deputados. (2011d), Homenagem. Diário do Congresso Nacional, Sessão Conjunta, LXVI, 9, 10 jun: 1342.

BRASIL. Congresso Nacional. Câmara dos Deputados. (2011e), Abertura. Diário do Congresso Nacional, Sessão Conjunta, LXVI, 15, 14-16 set: 2721.

BRASIL. Congresso Nacional. Câmara dos Deputados. (2011f). Ordem do dia. Diário da Câmara dos Deputados, LXVI, 165, 22 set: 53007.

BRASIL. Congresso Nacional. Câmara dos Deputados. (2011g). Ordem do dia. Diário da Câmara dos Deputados, LXVI, 165, 22 set: 53041.

BRASIL. Congresso Nacional. Câmara dos Deputados. (2012a). Ordem do dia. Diário da Câmara dos Deputados, LXVII, 31, 08 mar: 5819.

BRASIL. Congresso Nacional. Câmara dos Deputados. (2012b). Breves Comunicaçôes. Diário da Câmara dos Deputados, LXVII, 32, 09 mar: 6011.

BRASIL. Congresso Nacional. Câmara dos Deputados. (2012c). Ordem do dia. Diário da Câmara dos Deputados, LXVII, 47, 30 mar: 9543.

BRASIL. Congresso Nacional. Câmara dos Deputados. (2012d), Breves Comunicaçóes. Diário da Câmara dos Deputados, LXVII, 167, 11 out: 33206.

BRASIL. Congresso Nacional. Câmara dos Deputados. (2012e), Pequeno Expediente. Diário da Câmara dos Deputados, LXVII, 78, 17 mai: 17333. 
BRASIL. Congresso Nacional. Câmara dos Deputados. (2013), Breves Comunicaçôes. Diário da Câmara dos Deputados, LXVIII, 67, 24 abr: 11968.

BRASIL. Congresso Nacional. Câmara dos Deputados. (2014), Pequeno Expediente. Diário da Câmara dos Deputados, LXIX, 152, 16 out: 25.

BRASIL PARALELO. (2018), Entre mitos e verdades: a história do regime militar. [S.l.: s.n.].

CAPELATO, Maria Helena Rolim. (2016), "História do Brasil e Revisōes Historiográficas". Anos 90, Porto Alegre, 23, 43: 21-37.

CARDOSO, Irene.(2003), Para uma crítica do presente. São Paulo, Editora 34.

CARDOSO, Tom. (2011), O cofre do Dr. Rui: Como a Var-palmares de Dilma Rousseff realizou o maior assalto da Luta Armada brasileira. Rio de Janeiro: Civilização Brasileira.

CARVALHO, Luiz Maklouf. (2019), O cadete e o capitão: A vida de Jair Bolsonaro no quartel. Sáo Paulo, Todavia.

CORTE INTERAMERICANA DE DIREITOS HUMANOS (2010), Caso Gomes Lund e outros ("Guerrilha do Araguaia") vs. Brasil. Sentença de 24 de novembro de 2010.

FICO, Carlos. (2004), "Versōes e controvérsias sobre 1964 e a ditadura militar". Revista Brasileira de História, 24, 47: 29-60.

FITZPATRICK, Sheila. (2007), "Revisionism in Soviet History". History and Theme, 46: 77 - 91.

FIGUEIREDO, Argelina Cheibub. (2015), "O Brasil na encruzilhada", in A. Alonso \& M. Dolhnikoff (org.), 1964: Do Golpe à Democracia, São Paulo, Hedra, 27-41.

GLASSER, Barney \& STRAUSS, Anselm. (2006), The Discovery of Grounded Theory. Strategies for Qualitative Research. New Brunswick-London, Aldine Transaction.

MARTINS FILHO, João Roberto. (2008), “A influência doutrinária francesa sobre os militares brasileiros nos anos de 1960". Revista Brasileira de Ciências Sociais, 23, 67: 39-50.

MARTINS FILHO, João Roberto. (2019). O Palácio e a Caserna: A dinâmica militar das crises politicas na Ditadura (1964-1969). São Paulo, Alameda.
MELO, Demian Bezerra de. (2014), "Revisão e revisionismo na historiografia contemporânea", in D. B. de Melo (org.), A miséria da historiografia: uma crítica ao revisionismo contemporâneo, Rio de Janeiro, Consequência: 17-49.

MENDANHA, Soraya. VILAR, Isabela. (2013), "Congresso anula sessão que afastou Jango e abriu caminho para o Golpe de 1964". Senado Notícias, 21 de novembro.

MEZAROBBA, Glenda. (2009), "De que se fala, quando se diz 'Justiça de Transição'?". BIB. Revista Brasileira de Informação Bibliográfica em Ciências Sociais, 67: 111 - 122.

MOTTA, Rodrigo Patto Sá. (2018), "Cultura política e ditadura: um debate teórico e historiográfico". Tempo e Argumento, Florianópolis, 10, 23: 109 $-137$.

NAPOLITANO, Marcos. (2016), 1964: História do Regime Militar Brasileiro. São Paulo, Contexto.

NAPOLITANO, Marcos. (2017), "A imprensa e a construçáo da memória do regime militar brasileiro (1965 - 1985)". Estudos Ibero-Americanos, Porto Alegre, 43, 2: 346 - 366.

PEREIRA, Mateus Henrique de Faria. (2015), "Nova direita? Guerras de memória em tempos de Comissão da Verdade (2012-2014)". Varia Historia, 31 - 57: 863 - 902.

PINHA, Daniel. (2020), "A longa noite de 64: Bolsonaro e a experiência democrática vista do Parlamento". in V. Araújo, B. Klem, M. Pereira (org.), Do fake ao fato: Des(atualizando) Bolsonaro, Vitória, Editora Milfontes: 205-224 (4493 - 4952, Kindle Version).

POCOCK, John Greville Agard. (2003), Linguagens do Ideário Politico. São Paulo, EDUSP.

RIDENTI, Marcelo. (2010), O fantasma da revolução brasileira. São Paulo, Editora Unesp.

SANDOICA, Elena Hernández. (2004), Tendencias Historiográficas Actuales: Escribir Historia Hoy. Madrid, Ediciones Akal.

SILVA, Carla Luciana. (2014), "Imprensa e construção social da "ditabranda", in D. B. MELO, (org.), $A$ miséria da historiografia: uma crítica ao revisionismo contemporâneo, Rio de Janeiro, Consequência: 189-207. 
TOLEDO, Caio Navarro de. (2009), "Crônica política sobre um documento contra a 'ditabranda". Revista de Sociologia e Politica, Curitiba, 17, 34 : 209-217.

TRAVERSO, Enzo. (2017), "Revisão e Revisionismo", in C. Z. Sena Junior; D. B. de Melo \& G. G. Calil (org.), Contribuição à crítica da historiografia revisionista, Rio de Janeiro, Consequência Editora: $27-37$.

TUCKER, Aviezer. (2007), "Historiographic Revision and Revisionism: The Evidential Difference", in M. Kopecek (ed.), Past in the Making: Historical Revisionism in Central Europe after 1989, Budapest, CEU Press: 1 - 16.

VALENCIA-GARCIA, Louie Dean. (2020), "Far-Right Revisionism and the End of History", in L.D. Valencia-Garcia (org.), Far-Right Revisionism and the End of History, New York, Routledge: 3-26.
VALLE, Maria Ribeiro do. (2008), 1968: O diálogo é a violência. Campinas, Editora Unicamp.

VERBI Software. (2019), MAXQDA 2020 [computer software]. Available from maxqda.com. Berlin, VERBI Software.

VIDAL-NAQUET, Pierre. (1988), Os Assassinos da Memória: Um Eichmann de papel e outros ensaios sobre o revisionismo. Campinas, Papirus.

WAINBERG, Jacques Alkalai. (2010), “O embate pelo controle da memória traumática brasileira". Intexto, Porto Alegre, UFRGS, 2, 23: $50-68$.

ZAVERUCHA, Jorge. (2010), "Relaçôes CivilMilitares: O legado autoritário da Constituição Brasileira de 1988”. In V. Safatle, E. Teles (org.), O que resta da ditadura: a exceção brasileira. São Paulo, Boitempo. 


\section{O NEGACIONISMO NA OPOSIÇÁO DE JAIR BOLSONARO À COMISSÁO NACIONAL DA VERDADE}

\section{Pablo Emanuel Romero Almada}

Palavras-Chave: Negacionismo, Jair Bolsonaro, Ditadura Civil-Militar, Luta Armada, Comissão Nacional da Verdade.

$\mathrm{O}$ artigo analisa os discursos realizados pelo então Deputado Federal Jair Bolsonaro em torno da Lei No 12.528/ 2011, que estabeleceu a Comissão Nacional da Verdade (CNV). Entende-se que esses discursos, proferidos na Câmara dos Deputados e no Congresso Nacional, são essenciais para a compreensão de uma linguagem política negacionista sobre a ditadura civil-militar brasileira e dos conflitos suscitados pelo reconhecimento da memória. Debate-se como esses discursos reiteram a permanência do passado autoritário, mediante tentativas de manipulação do passado e de construção de versóes alteradas dos fatos no presente. A pesquisa seguiu por evidenciar os argumentos de defesa da ditadura civilmilitar e de associação da esquerda com a criminalidade, concluindo por refletir sobre suas sustentaçóes a partir das visóes da imprensa de 1964.

\section{NEGATIONISM IN JAIR BOLSONARO'S OPPOSITION TO THE NATIONAL TRUTH COMMISSION}

Pablo Emanuel Romero Almada

Keywords: Negationism, Jair Bolsonaro, Civil-Military Dictatorship, Armed Struggle, National Truth Commission.

This article analyzes the speeches made by then Federal Congressperson Jair Bolsonaro regarding Law No. 12,528/2011, which established the National Truth Commission (NTC). It is understood that these speeches, given in the Chamber of Deputies and in the National Congress, are essential for the understanding of the negative political language concerning the Brazilian civilmilitary dictatorship and the conflicts raised by memory recognition. We debate how these speeches reiterate the permanence of an authoritarian past, through attempts to manipulate the past and construct altered versions of the facts in the present. The research goes on to highlight arguments for the defense of a civil-military dictatorship and the left's association with crime, concluding by reflecting on its support from 1964 press views.

\section{LE NÉGATIONNISME DANS L'OPPOSITION DE JAIR BOLSONARO À LA COMMISSION NATIONALE DE LA VÉRITÉ}

Pablo Emanuel Romero Almada

Mots-clés: négationnisme, Jair Bolsonaro; dictature civile-militaire, lutte armée, Commission nationale de la vérité.

L'article analyse les discours de Jair Bolsonaro, alors député fédéral, autour de la Loi n¹2528/2011, à l'origine de la Commission nationale de la vérité. Prononcés à la Chambre des députés et au Congrès, ces discours renferment un langage politique négationniste sur la dictature civile-militaire brésilienne et sur les conflits suscités par la reconnaissance de la mémoire. Ils réitèrent la permanence d'un passé autoritaire à travers des tentatives de manipulation du passé et des versions altérées des faits au présent. La recherche met en évidence les arguments de défense de la dictature civile-militaire et l'association entre la gauche et la criminalité, tout en interrogeant les points de vue des médias en 1964 . 